\title{
Screening of Beneficial Microorganisms to Improve Soybean Growth and Yield
}

\author{
Mariana Aguiar Silva ${ }^{1^{*}}$ \\ https: //orcid.org/0000-0003-0297-5576
}

Adriano Stephan Nascente ${ }^{2}$

https://orcid.org/0000-0002-6014-3797

\section{Marta Cristina Corsi de Filippi ${ }^{2}$}

https://orcid.org/0000-0003-1676-8164

Anna Cristina Lanna ${ }^{2}$

https://orcid.org/ 0000-0001-8018-9349

\author{
Gisele Barata da Silva ${ }^{3}$ \\ https://orcid.org/0000-0002-6064-7864
}

João Pedro Tavares Fernandes ${ }^{1}$

https://orcid.org/0000-0003-2162-6654

\author{
Marina Teixeira Arriel Elias 1 \\ https://orcid.org/0000-0003-2026-4989
}

${ }^{1}$ Federal University of Goiás; Goiânia, Goiás, Brazil; ${ }^{2}$ Embrapa Rice and Beans; Santo Antônio de Goiás, Goiás, Brazil;

${ }^{3}$ Plant Protection Laboratory. Institute of Agrarian Sciences. Federal Rural University of Amazon; Belém, Pará, Brazil.

Received: 2019.07.30; Accepted: 2020.03.30.

*Correspondence: M.A.S marianaaguiar23@hotmail.com; Tel.: +55-64-999336200

HIGHLIGHTS

- We tested co inoculation in the development of soybean plants.

- Microorganisms provided better soybean development than in the control plants;

- Ab-V5 + Trichoderma asperellum pool provided 25\% more soybean grain yield.

Abstract: The objective of this research was to identify the best microorganisms, alone or in mixture for total biomass gain (root + shoot), positive change in gas exchange, nutrient uptake (root, shoot and grain) and yield and yield components in the soybean crop. Trial under greenhouse conditions had the experimental design in a completely randomized scheme with 26 treatments and four replicates. The treatments consisted of the rhizobacteria BRM 32109, BRM 32110 and 1301 (Bacillus sp.), BRM 32111 and BRM 32112 (Pseudomonas sp.), BRM 32113 (Burkholderia sp.), BRM 32114 (Serratia sp.), Ab-V5 (Azospirillum brasilense) and 1381 (Azospirillum sp.), and the fungus Trichoderma asperellum (a mix of the isolates UFRA.T06, UFRA.T09, UFRA.T12 and UFRA.T52). Besides, the same isolates were combined in pairs, completing 16 combinations. Control treatments received no microorganism. Microorganisms applied isolated or in combination, provided biomass gain, positive gas exchange, increases in nutrients uptake at the shoot and grain, and improved grain yield and its components than control plants. Stood out the combination $\mathrm{Ab}-\mathrm{V} 5+\mathrm{T}$. asperellum pool, which provided a $25 \%$ improvement in grain yield.

Keywords: g/ycine max; bioagent; growth promotion; nutrient uptake; gas exchange; grain yield.

\section{INTRODUCTION}

The inoculation of plant growth promoting rhizobacteria (PGPR) represents a strategic alternative for sustainable agricultural systems [1]. This group of microorganisms can benefit the plant via multiple mechanisms, which have been divided into direct and indirect stimulation. A co-inoculation consists of adding 
more than one recognized beneficial microorganism to the plants in order to maximize their contribution to plant development.

The plant growth promotion by Trichoderma $\mathrm{sp}$ is due to the production of specific metabolites, such as growth stimulants (phytohormones), hydrolytic enzymes, siderophores, antibiotics, and carbon and nitrogen permeases. These characteristics allow it to act as a growth bio-promoter, ensuring that the plant has access to nutrients solubilized by the fungus (especially phosphates), which are not available in the soil [2]. The ability of the fungus to colonize roots is a critical factor for its interference with plant growth and productivity [3].

Studies of Embrapa Rice and Bean and the Federal Rural University of Amazonia allowed the identification of beneficial rhizobacteria (BRM 32109, BRM 32110, BRM 32111, BRM 32112, BRM 32113, BRM 32114, 1301, AbV5 and 1381), collected from upland rice fields [4] and four isolates of the fungus Trichoderma asperellum (UFRA.T06, UFRA.T09, UFRA.T12, UFRA.T52), collected from reforestation rhizosphere soil and Amazon native forest [5],[6] . After selection and characterization, research carried out in the greenhouse proved the potential of these microorganisms, since significant increases were observed in the gas exchange and biomass production of irrigated [7] and upland rice [8]. The same species of beneficial microorganisms can promote the growth of several plant species [9]. Thus, the objective of this research was to identify the best microorganisms, alone or in the mixture for total biomass gain (root + shoot), positive change in gas exchange, nutrient uptake (root, shoot and grain), yield components and grain yield of the soybean crop.

\section{MATERIAL AND METHODS}

The study was conducted in a greenhouse condition at the headquarters of Embrapa Rice and Bean, in the municipality of Santo Antônio de Goiás, GO, Brazil. Arable layer soil $(0-0.20 \mathrm{~m})$ of a dark red Latosol (Árico) [10] of a pasture of Urochloa brizantha for more than 20 years was used. The soil chemical characteristics were determined according to the methods described by [11] (Table 1).

Table 1.Soil characteristics used to fill the posts where soybean (Glycine max (L.) Merril) plants were planted in the experiment conductin 2018 at Embrapa Rice and Beans

$\mathrm{pH} \mathrm{Ca}{ }^{2+} \mathrm{Mg}^{2+} \mathrm{Al}^{3} \mathrm{H}^{+}+\mathrm{Al}^{3} \quad \mathrm{P} \quad \mathrm{K} \quad \mathrm{Cu}^{2+} \mathrm{Zn}^{2+} \mathrm{Fe}^{3+} \mathrm{Mn}^{2+}$ SOM Clay Silt Sand

$\left(\mathrm{H}_{2} \mathrm{O}\right)$

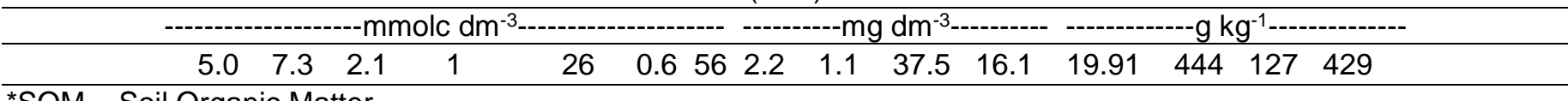

${ }^{*} \mathrm{SOM}$ - Soil Organic Matter

Three weeks before soybean sowing, the $10 \mathrm{~kg}$ pots were completely filled with soil and fertilized with 10 grams of $\mathrm{N}-\mathrm{P}_{2} \mathrm{O}_{5}-\mathrm{K}_{2} \mathrm{O}$ (5-30-15). For nitrogen supply, the liquid inoculant (Bradyrhizobium japonicum) was pulverized in the seeding groove, including the control treatment. For this, $5 \mathrm{~mL}$ of the commercial product "Grap Nod" was diluted in $900 \mathrm{~mL}$ of water, and $10 \mathrm{~mL}$ of the solution was applied per pot.

The experimental design was a completely randomized scheme with 26 treatments (Table 2) and four replicates, under greenhouse conditions. Treatments consisted of the microbiolization of soybean seeds with microorganisms, isolated, and in mixing pairs. Besides, the application of microbial suspension on the $7^{\text {th }}$ and $21^{\text {st }}$ at the soil and soybean seedlings, respectively. 
Table 2. Treatments (isolated microorganisms and/or a mixture of microorganisms) of the beneficial microorganisms with soybean (Glycine max (L.) Merril) experiment, conducted in 2018 at Embrapa Rice and Beans.

\begin{tabular}{cl}
\hline Treatment & Microorganism(s) \\
\hline 1 & BRM 32109 \\
2 & BRM 32110 \\
3 & BRM 32111 \\
4 & BRM 32112 \\
5 & BRM 32113 \\
6 & BRM 32114 \\
7 & 1301 \\
8 & 1381 \\
9 & T. asperellum pool \\
10 & Ab-V5 \\
& \\
11 & BRM 32114 + BRM 32110 \\
12 & BRM 32114 + Ab-V5 \\
13 & BRM 32114 + T. asperellum pool \\
14 & BRM 32110 + Ab-V5 \\
15 & BRM 32110 + T. asperellum pool \\
16 & Ab-V5 + T. asperellum pool \\
17 & $1381+1301$ \\
18 & $1381+$ Ab-V5 \\
19 & $1301+$ Ab-V5 \\
20 & $1381+$ BRM 32114 \\
21 & $1301+$ BRM 32114 \\
22 & $1381+$ BRM 32110 \\
23 & $1301+$ BRM 32110 \\
24 & $1381+$ T. asperellum pool \\
25 & $1301+$ T. asperellum pool \\
26 & Control (no microorganism) \\
\hline
\end{tabular}

The main characteristics of the isolates of rhizobacteria: Bacillus sp. (BRM 32109, BRM 32110 and 1301), Pseudomonas sp. (BRM 32111 and BRM 32112), Burkholderia sp. (BRM 32113), Serratia sp. (BRM 32114), Azospirillum brasilense (Ab-V5) and Azospirillum sp. (1381) are described in Table 3. The rhizobacteria are stored and preserved in the collection of Multifunctional Microorganisms of Embrapa Rice and Beans. The T. asperellum pool is stored and preserved in the Collection of Fungal Cultures of the Plant Protection Laboratory of the Federal Rural University of Amazonia.

Table 3. Collection code, geographical origin, biochemical characteristics and taxonomic classification of the eight rhizobacteria isolates used to treat soybean seeds

\begin{tabular}{|c|c|c|c|c|c|c|c|c|}
\hline \multirow[b]{2}{*}{ Code $^{A}$} & \multirow[b]{2}{*}{ Origin $^{B}$} & \multirow[b]{2}{*}{ Color } & \multicolumn{5}{|c|}{ BiochemicalD } & \multirow[b]{2}{*}{ Taxonomic $^{\mathrm{E}}$} \\
\hline & & & $\begin{array}{l}\text { AlA } \\
F\end{array}$ & Celul. $^{\mathrm{G}}$ & phos $_{\text {or }}{ }^{p h}$ & Sider. ${ }^{1}$ & Biofilm $^{J}$ & \\
\hline BRM 32109 & GO/Brazil & White & & + & + & & + & Bacillus sp. \\
\hline BRM 32110 & PA/Brazil & White & & + & + & + & + & Bacillus sp. \\
\hline BRM 32111 & PA/Brazil & Yellow & & + & + & + & + & Pseudomonas sp. \\
\hline BRM 32112 & GO/Brazil & Yellow & & + & + & + & + & Pseudomonas sp. \\
\hline BRM 32113 & PA/Brazil & Pink & + & + & & + & + & Burkholderia sp. \\
\hline BRM 32114 & PA/Brazil & Pink & + & + & + & + & + & Serratia sp. \\
\hline$A b-V 5$ & PR/Brazil & Yellow & + & + & + & + & + & Azospirillum sp. \\
\hline 1381 & & White & + & + & + & + & + & Azospirillum sp. \\
\hline 1301 & & White & + & + & + & + & + & Bacillus sp. \\
\hline
\end{tabular}

Number code of rhizobacterial isolates in the Microorganisms and fungi Multifunction Embrapa Rice and Beans collection geographical origin of each isolate; C, D, colony color, Biochemical characterization and Taxonomic classification of each isolate, described by [11]; F acid idol acetic producer; Gcelulase producer; Phosphatase producer; Isiderophers producer; biofilm producer. The methodology is described in [11].

Bacterial suspensions for seed microbiolization and applications were prepared with water from cultures grown for 24 hours in solid medium 523 [13] at $28^{\circ} \mathrm{C}$, and the suspension concentration of each of the bacteria was fixed in spectrophotometer for A540 $=0.5$ (108 CFU mL ${ }^{-1}$, Colony-Forming Unit). Soybean seeds were immersed in a suspension of microorganisms, according to treatment, and the control seeds were immersed in water for a period of 4 hours under constant agitation at $25^{\circ} \mathrm{C}$. For $T$. asperellum, each 
isolate was grown in Petri dishes containing PDA (dextrose and potato agar) for 5 days and bioformed [5]. Seed treatment was carried out at concentrations of $10 \mathrm{~g}$ of $T$. asperellum powder per $1 \mathrm{~kg}$ of seeds [4], [5]. The suspension concentration of each T. asperellum pool isolate was fixed at $108 \mathrm{ml}^{-1}$ conidia, and then the isolates were mixed in equal volumes.

Soybean seed microbiolization was based on the methodology used for rice seeds microbiolization, proposed by [4], with an adaptation. Before proceeding soybean microbiolization, we performed a test to determine the optimal period of time for seeds and bacterial suspension contact, The seeds were submersed in a suspension containing water and the isolate BRM 32110 (Bacillus spp.), during different times period (2 hours, 4 hours, 6 hours and 16 hours), and only water (control treatment), totaling 5 treatments and 4 repetitions. Seeds were taken out from suspension dried at room temperature, and sown in $500 \mathrm{~mL}$ cups. The best time period was determined by identifying the highest seedling sown, 15 days after sowing. The treatment that provided the best results was the microbiolization for 4 hours. Therefore, this methodology was used in this experiment.

Ten soybean seeds, cultivar BRS 6970IPRO, were sown per pot in August 2018. Four days after occurred germination, and the thinning of plants was done, maintaining three plants per pot. The cultural practices were carried out according to the recommendations and needs of the crop aiming at keeping the pots free of weeds, diseases and pest insects.

Microbial suspension similar to that used for soybean seed microbiolization was applied to the soil at 7th days after sowing (DAS) and sprayed onto soybean plants at 21th DAS. These applications were made as follows:

- Application to the soil: microbial suspension $\left(100 \mathrm{~mL}, 10^{8} \mathrm{CFU} \mathrm{mL}{ }^{-1}\right.$ for each rhizobacterium and $10^{8}$ conidia $\mathrm{mL}^{-1}$ for $T$. asperellum isolates) or water (control) was applied to each plot (vase);

- Application to the seedlings: microbial suspension $\left(30 \mathrm{~mL}, 10^{8} \mathrm{CFU} \mathrm{mL} \mathrm{m}^{-1}\right.$ for each rhizobacterium and $10^{8}$ conidia $\mathrm{mL}^{-1}$ for $T$. asperellum isolates) or water (control) was applied to each plot. Hand sprayer with a constant pressure supplied by a $\mathrm{CO}_{2}$ pressure source and a type of conical nozzle (TX-VS2) on $21^{\text {th }}$ DAS was used.

The following evaluations were carried out:

Measurements were performed using an infrared gas analyzer (LCpro +, ADC BioScientific, Hoddesdon, England) (Table 4). A soybean plant per pot was used to perform measurements of gas exchange, totaling four plants for each treatment. Gas exchange measurements were performed in the central leaflets of the upper third of soybean plants (completely expanded and exposed to sunlight).

Table 4. Gas exchange parameters obtained from IRGA (infrared gas analyzer).

\begin{tabular}{llllll}
\hline Parameters & $\begin{array}{l}\mathrm{A} \\
\text { Photosynthetic } \\
\text { rate }\end{array}$ & $\begin{array}{l}\mathrm{E} \\
\text { Transpiratory rate }\end{array}$ & $\begin{array}{l}\text { gs } \\
\text { Stomatal } \\
\text { conductance }\end{array}$ & $\begin{array}{l}\mathrm{Ci} \\
\text { Internal } \mathrm{CO}_{2} \\
\text { concentration }\end{array}$ & $\begin{array}{l}\text { Instantaneous } \\
\text { Carboxylation } \\
\text { Efficiency }\end{array}$ \\
\hline \multirow{2}{*}{ Unit } & $\left(\mu \mathrm{mol} \mathrm{CO} \mathrm{m}^{-2} \mathrm{~s}^{-1}\right)$ & $\left(\mathrm{mmol} \mathrm{H}_{2} \mathrm{O} \mathrm{m}^{-2} \mathrm{~s}^{-1}\right)$ & $\left(\mathrm{mol} \mathrm{H}_{2} \mathrm{O} \mathrm{m}^{-2} \mathrm{~s}^{-1}\right)$ & $\left.(\mu \mathrm{mol} \mathrm{mol})^{-1}\right)$ & $\begin{array}{l}\left(\mu \mathrm{mol} \mathrm{m}^{-2} \mathrm{~s}^{-1}\right) \\
\left.\left(\mu \mathrm{mol} \mathrm{mol}^{-1}\right)^{-1}\right)\end{array}$ \\
\hline
\end{tabular}

${ }^{*}$ The instantaneous efficiency of carboxylation (EiC) was calculated by the ratio between $\mathrm{A}$ and $\mathrm{Ci}$ [13].

The readings were made in the period between 08:00, and 10:00 am in the full bloom of soybean plants. The equipment was regulated to use concentrations of $370-400 \mathrm{~mol} \mathrm{~mol}^{-1} \mathrm{CO}_{2}$ in the reference air used in the IRGA photosynthesis chamber. The flux of photosynthetically active photons (DFFFA) used was 1200 $\mu \mathrm{mol}$ [quanta] $\mathrm{m}^{-2} \mathrm{~s}^{-1}$. The minimum equilibrium time established for the reading was 2 minutes.

When the soybean plants reached full bloom stage, the shoot of one plant per pot was randomized removed; washed in water; packed in paper bags, previously identified; dried in an oven with forced-air circulation at $65^{\circ} \mathrm{C}$ for $72 \mathrm{~h}$ and, then, weighed. Roots were measured in the two left plants after harvesting grain yield and yield components using the same methodology. Dry biomass of shoot, root and total (shoot + root) were determined.

When soybean plants reached physiological maturity at 116 days after sowing, the harvest occurred. The number of pods per plant, number of grains per pot, mass of 100 grains and grain yield were determined. Grain yield was determined by weighing total grains harvested from each pot, and the moisture content of the grains was corrected to $13 \%$ and converted to $\mathrm{g}^{-1}$ plant. Number of pod per plant was determinate by counting pods number in each pot and dividing by two. Number of grains per pod was determinate by counting the number of grains of a sample of 10 pods randomly collected and divided by 10 . Mass of 100 grains, randomly collected, were weighed and the moisture content of the grains corrected to $13 \%$. 
Shoot, root and grains after drying were ground (Willey mill) for analysis and determination of nutrients content $(\mathrm{N}, \mathrm{P}, \mathrm{K}$ and $\mathrm{Fe})$. Nitrogen was extracted with $\mathrm{H}_{2} \mathrm{SO}_{4}$. From the extracted solution, the $\mathrm{N}$ concentration was determined using the Kjeldahl distillation method [14]. Phosphorus and exchangeable $\mathrm{K}$ were extracted with a Mehlich1 extracting solution $\left(0.05 \mathrm{M} \mathrm{HCl}\right.$ in $\left.0.0125 \mathrm{M} \mathrm{H}_{2} \mathrm{SO}_{4}\right)$. The extracts were calorimetrically analyzed for $\mathrm{P}$, and flame photometry was used to analyze K. Iron was determined in a Mehlich1 extract by atomic absorption [11].

The data were submitted to analysis of variance, and when significant, the means were compared by the LSD test ( $\alpha \leq 0.05)$. The SAS Statistical Software, SAS Institute, Cary, NC, USA (SAS, 1999) was used.

\section{RESULTS AND DISCUSSION}

The analysis of variance revealed that there were differences in the values of $A$ and EiC in soybean, cultivar BRS 6970IPRO, inoculated and treated with the different microorganisms, isolated and in combination (Table 5). Thus, soybean treated with combinations $1301+\mathrm{BRM} 32110$ and $1301+\mathrm{Ab}-\mathrm{V} 5$ had the highest $A$ values when compared to treatments $1381+T$. Asperellum pool, $1301+32114,1381+32114$, $1381+32110,1381+\mathrm{Ab}-\mathrm{V} 5, \mathrm{Ab}-\mathrm{V} 5+\mathrm{T}$. Asperellum pool, BRM 32109, BRM 32111 and 1301, but did not differ statistically from the other treatments or the control. Soybean plants co-inoculated with $1301+\mathrm{Ab}-\mathrm{V} 5$ also provided highest $\mathrm{EiC}$, compared to the control treatment. In our research we could see that microorganisms provided differences in only one variable (EiC). Therefore, we can see that microorganisms used in this trial had little effect on gas exchange. However, these microorganisms can have effect in other variables that affects plant development with effect on grain yield. [7] reported that although microorganisms did not have high effect on gas exchange in relation to the control treatment, they provided significant improvements on irrigated rice yield.

Table 5. Photosynthesis (A), transpiration (E), stomatal conductance (gs), $\mathrm{CO}_{2}$ internal concentration (Ci) and instantaneous carboxylation efficiency (EiC) of soybean plants, BRS 6970IPRO, co-inoculated with beneficial microorganisms, isolated and in combination.

\begin{tabular}{llllll}
\hline Microorganisms & $\mathrm{A}$ & $\mathrm{E}$ & $\mathrm{Gs}$ & $\mathrm{Ci}$ & $\mathrm{EiC}$ \\
\cline { 2 - 6 } & $\left(\mu \mathrm{mol} \mathrm{CO}_{2} \mathrm{~m}^{-2} \mathrm{~s}^{-1}\right)$ & $\left(\mathrm{mmol} \mathrm{H}_{2} \mathrm{O} \mathrm{m}^{-2} \mathrm{~s}^{-1}\right)$ & $\left(\mathrm{mol} \mathrm{H}_{2} \mathrm{O} \mathrm{m}^{-2} \mathrm{~s}^{-1}\right)$ & $\left(\mu \mathrm{mol} \mathrm{mol}^{-1}\right)$ & $\begin{array}{c}\left(\mu \mathrm{mol} \mathrm{m}^{-2} \mathrm{~s}^{-1}\right) \\
\left(\mu \mathrm{mol}^{-1}\right)^{-1}\end{array}$ \\
32109 & $8.05 \mathrm{c}$ & 3.96 & 0.79 & 341 & $0.024 \mathrm{c}$ \\
32110 & $12.67 \mathrm{abc}$ & 3.37 & 0.58 & 299 & $0.043 \mathrm{abc}$ \\
32111 & $9.99 \mathrm{bc}$ & 3.75 & 0.68 & 296 & $0.035 \mathrm{abc}$ \\
32112 & $12.18 \mathrm{abc}$ & 2.86 & 0.44 & 280 & $0.044 \mathrm{abc}$ \\
32113 & $11.02 \mathrm{abc}$ & 2.92 & 0.54 & 308 & $0.038 \mathrm{abc}$ \\
32114 & $20.96 \mathrm{abc}$ & 2.79 & 0.51 & 265 & $0.076 \mathrm{ab}$ \\
1301 & $10.01 \mathrm{bc}$ & 2.89 & 0.51 & 256 & $0.040 \mathrm{abc}$ \\
1381 & $11.60 \mathrm{abc}$ & 3.56 & 0.68 & 297 & $0.042 \mathrm{abc}$ \\
Trichoderma pool & $18.58 \mathrm{abc}$ & 3.59 & 0.63 & 318 & $0.060 \mathrm{abc}$ \\
Ab-V5 & $19.51 \mathrm{abc}$ & 3.75 & 0.79 & 318 & $0.060 \mathrm{abc}$ \\
$32114+32110$ & $12.32 \mathrm{abc}$ & 3.70 & 0.51 & 289 & $0.044 \mathrm{abc}$ \\
$32114+$ Ab-V5 & $15.18 \mathrm{abc}$ & 3.66 & 0.60 & 278 & $0.053 \mathrm{abc}$ \\
$32114+$ T. pool & $24.88 \mathrm{ab}$ & 2.42 & 0.40 & 292 & $0.079 \mathrm{ab}$ \\
$32110+$ Ab-V5 & $12.97 \mathrm{abc}$ & 3.85 & 0.91 & 312 & $0.043 \mathrm{abc}$ \\
$32110+$ T. pool & $17.45 \mathrm{abc}$ & 3.39 & 0.52 & 292 & $0.059 \mathrm{abc}$ \\
Ab-V5+ T. pool & $9.29 \mathrm{c}$ & 4.36 & 1.03 & 341 & $0.028 \mathrm{c}$ \\
$1381+1301$ & $12.55 \mathrm{abc}$ & 3.47 & 0.64 & 283 & $0.045 \mathrm{abc}$ \\
$1381+$ Ab-V5 & $8.95 \mathrm{c}$ & 3.55 & 0.60 & 322 & $0.027 \mathrm{c}$ \\
$1301+$ Ab-V5 & $25.24 \mathrm{a}$ & 4.03 & 0.79 & 312 & $0.080 \mathrm{a}$ \\
$1381+32114$ & $9.21 \mathrm{c}$ & 3.51 & 0.58 & 255 & $0.049 \mathrm{abc}$ \\
$1301+32114$ & $7.55 \mathrm{c}$ & 2.93 & 0.48 & 320 & $0.023 \mathrm{c}$ \\
$1381+32110$ & $9.64 \mathrm{c}$ & 2.27 & 0.38 & 273 & $0.037 \mathrm{abc}$ \\
$1301+32110$ & $25.25 \mathrm{a}$ & 3.59 & 0.58 & 361 & $0.066 \mathrm{abc}$ \\
$1381+$ T. pool & $6.87 \mathrm{c}$ & 3.29 & 0.51 & 303 & $0.026 \mathrm{c}$ \\
$1301+$ T. pool & $12.36 \mathrm{abc}$ & 2.88 & 0.49 & 278 & $0.044 \mathrm{abc}$ \\
\hline No microorganism & $10.25 \mathrm{abc}$ & 3.88 & 0.68 & 324 & $0.032 \mathrm{bc}$ \\
\hline
\end{tabular}

${ }^{*}$ Means followed by the same letter do not differ from each other by the LSD test. BRM 32109, BRM 32110 and 1381 Bacillus sp., BRM 32111 Burkholderia sp., BRM 32112 and BRM 32113 - Pseudomonas sp, Ab-V5 - Azospirillum sp., 1301 - Azospirillum brasilense, T. asperellum pool (UFRA-06, UFRA- 09, UFRA-12 and UFRA-52).

The 1381 (Azospirillum sp) + BRM 32114 (Serratia sp.) treatment differed statistically from the other treatments for greater shoot biomass production, including the control treatment (Table 6). In addition to 
soybean inoculation with Bradyrhizobium, the use of growth-promoting bacteria of the genus Azospirillum has been promising, as they may increase the root system and the volume of soil explored, thus influencing soybean nodulation and efficient nutrient absorption, which consequently provides higher biomass production and crop yield [15]. In a similar study, there was also an increase in shoot biomass and roots in soybean plants inoculated with Azospirillum sp [16]. Bacteria of the genus Serratia sp also promote plant growth and increase biomass production through phytohormones production, $\mathrm{P}$ solubilization and increased root development, allowing for greater nutrient absorption [7].

Soybean plants treated with the isolate 1301 (Bacillus sp.) and mixture 1301 + BRM 32114 (Serratia sp.) were significantly superior to control plants for root dry biomass (Table 6). The 1301 + BRM 32114 treatment also provided higher total biomass of soybean plants, being significantly superior to the control treatment. These results showed that the co-inoculation of the soybean with beneficial microorganisms, isolated or in combination, can provide significant increases in shoot and root biomass. Likewise, [17] showed that soybean inoculation with Bacillus subtilis increased shoot and root dry biomass in Gurupi and Araguaçu regions.

Table 6. Dry matter of shoot, root and total (shoot + root) of soybean, BRS 6970IPRO, co-inoculated with several beneficial microorganisms, isolated and in combination.

\begin{tabular}{|c|c|c|c|}
\hline \multirow[t]{2}{*}{ Microorganism } & Shoot & Root & Total \\
\hline & \multicolumn{3}{|c|}{-----------------grams plant'1------------- } \\
\hline 32109 & 5.07 cde & $22.14 \mathrm{~cd}$ & $27.22 \mathrm{~cd}$ \\
\hline 32110 & 4.93 cde & $26.07 \mathrm{bcd}$ & $31.00 \mathrm{bcd}$ \\
\hline 32111 & $4.63 \mathrm{de}$ & $24.85 \mathrm{bcd}$ & $29.48 \mathrm{bcd}$ \\
\hline 32112 & $4.53 \mathrm{e}$ & $21.87 \mathrm{~cd}$ & $26.40 \mathrm{~cd}$ \\
\hline 32113 & 5.62 bcde & $26.27 \mathrm{bcd}$ & $31.89 \mathrm{bcd}$ \\
\hline 32114 & 5.44 bcde & $20.45 d$ & $25.90 \mathrm{~d}$ \\
\hline 1301 & 5.20 bcde & $37.95 a b$ & $43.15 \mathrm{ab}$ \\
\hline 1381 & 6.43 bcde & $26.87 \mathrm{bcd}$ & $25.90 \mathrm{~d}$ \\
\hline T. asperellum pool & $6.78 \mathrm{ab}$ & $28.95 \mathrm{bcd}$ & $35.73 \mathrm{abcd}$ \\
\hline Ab-V5 & 5.29 bcde & $24.21 \mathrm{bcd}$ & $29.50 \mathrm{bcd}$ \\
\hline $32114+32110$ & 5.10 cde & $24.58 \mathrm{bcd}$ & $29.69 \mathrm{bcd}$ \\
\hline $32114+A b-V 5$ & $6.13 \mathrm{bcd}$ & $26.91 \mathrm{bcd}$ & $33.04 \mathrm{bcd}$ \\
\hline $32114+T$. asperellum pool & 5.68 bcde & $15.47 \mathrm{~d}$ & $21.16 \mathrm{~d}$ \\
\hline $32110+A b-V 5$ & $6.42 \mathrm{abc}$ & $20.21 \mathrm{~d}$ & $26.64 \mathrm{~cd}$ \\
\hline $32110+$ T. asperellum pool & 5.48 bcde & $35.72 a b c$ & $41.21 \mathrm{abc}$ \\
\hline $\mathrm{Ab}-\mathrm{V} 5+T$. asperellum pool & 6.09 bcde & $24.69 \mathrm{bcd}$ & $30.79 \mathrm{bcd}$ \\
\hline $1381+1301$ & 5.58 bcde & $27.08 \mathrm{bcd}$ & $32.66 \mathrm{bcd}$ \\
\hline $1381+A b-V 5$ & $6.20 \mathrm{bcd}$ & $21.83 \mathrm{~cd}$ & $28.03 \mathrm{~cd}$ \\
\hline $1301+A b-V 5$ & 5.80 bcde & $24.95 \mathrm{bcd}$ & $30.76 \mathrm{bcd}$ \\
\hline $1381+32114$ & $7.84 \mathrm{a}$ & $27.16 \mathrm{bcd}$ & $35.00 \mathrm{bcd}$ \\
\hline $1301+32114$ & $6.45 \mathrm{abc}$ & $43.45 \mathrm{a}$ & $49.90 \mathrm{a}$ \\
\hline $1381+32110$ & 5.79 bcde & $25.59 \mathrm{bcd}$ & $31.38 \mathrm{bcd}$ \\
\hline $1301+32110$ & 5.76 bcde & $29.21 \mathrm{bcd}$ & $34.97 \mathrm{bcd}$ \\
\hline $1381+T$. asperellum pool & $6.11 \mathrm{bcd}$ & $25.16 \mathrm{bcd}$ & $31.27 \mathrm{bcd}$ \\
\hline $1301+T$. asperellum pool & 5.93 bcde & $18.32 \mathrm{~d}$ & $24.26 \mathrm{~d}$ \\
\hline No microorganism & 5.51 bcde & $22.89 \mathrm{~cd}$ & $28.40 \mathrm{bcd}$ \\
\hline
\end{tabular}

${ }^{*}$ Means followed by the same letter do not differ from each other by the LSD test. BRM 32109, BRM 32110 and 1381 Bacillus sp., BRM 32111 Burkholderia sp., BRM 32112 and BRM 32113 - Pseudomonas sp, Ab-V5 - Azospirillum sp., 1301 - Azospirillum brasilense, T.asperellum pool (UFRA-06, UFRA- 09, UFRA-12 and UFRA-52).

Some genera of PGPR favor plant growth directly by synthesizing growth regulators (such as auxins) as well as solubilizing phosphates and zinc and/or producing siderophores [18]. Other microorganisms act indirectly by preserving plant growth through biological control, phytoalexin production, or induce plant resistance in the presence of pathogens [19]. In our study, the beneficial microorganisms evaluated, as shown in Table 3, are auxin, cellulase, siderophores and exopolysaccharides producers and phosphate solubilizers. Therefore, the higher development of soybean plants due to microorganisms treatment is likely because of the production of these composts.

Regarding nitrogen $(\mathrm{N})$ uptake and accumulation in the shoot, none of the treatments were significantly superior to the control. The treatments BRM 32110, BRM $32110+$ Ab-V5, BRM $32114+T$. asperellum pool, BRM 32109, BRM 32111, 1301, BRM 32112, T. asperellum pool, $1381+T$. asperellum pool were significantly higher than the others treatments (Table 7). 
It was possible to see higher phosphorus $(\mathrm{P})$ uptake and accumulation in plants treated with microorganisms (Table 7). The highlight was soybean plants treated with BRM 32110 (Bacillus sp.) $+T$. asperellum pool compared to the control. Our results corroborate those of [20], found that in a soybean experiment, several Bacillus isolates with natural phosphate fertilization provided higher phosphorus content in the shoots of soybean plants and soil than in the control treatment (without Bacillus inoculation). Furthermore, Trichoderma fungi are also indicated as efficient for solubilizing phosphates and increasing soil fertility and plant growth [21]. Therefore, the association of the Bradyrizhobium, Bacillus sp. and Trichoderma pool may have favored the higher phosphorus accumulation in soybean shoots in response to the higher root system development and the ability of these microorganisms to perform phosphorus solubilization.

The treatment BRM 32113 (Burkholderia sp.) was superior to control treatment for potassium accumulation in soybean plants (Table 7). Potassium is fundamental in regulating the osmotic potential of cells and increasing the specific surface of the root system [22]. In this experiment, the isolate BRM 32113 provided higher $\mathrm{K}$ accumulation in the shoots, although it had no effect on root biomass. This suggests greater availability of $\mathrm{K}$ in the soil solution and possible improvement in the absorption mechanism of this nutrient but not in the biomass accumulation.

BRM 32111 (Pseudomonas sp.), 1381 (Azospirillum sp.) + BRM 32110 (Bacillus sp.) and 1381 (Azospirillum sp.) $+T$. asperellum pool differed statistically from control treatment, providing a greater accumulation of iron in soybean plants (Table 7). Both rhizobacteria and Trichoderma asperellum pool produce siderophores, which can be defined as small peptide molecules containing side chains and functional groups that can provide a high-affinity set of ligands to coordinate ferric ions [23]. Siderophores can chelate ferric ion with high affinity, allowing its solubilization and extraction from most mineral or organic complexes [24]. In soil, siderophore production activity plays a central role in determining the ability of different microorganisms to improve plant development. Microbial siderophores enhance iron uptake by plants that are able to recognize the bacterial ferric-siderophore complex [25] and are also important in the iron uptake by plants in the presence of other metals such as nickel and cadmium [25]. Soybean plants benefit from siderophores production by facilitating the acquisition of $\mathrm{Fe}$, which participates in various enzymatic functions, including protein synthesis [26]. Evaluating the effect of beneficial rhizobacteria on upland rice plants, [7] also observed higher values of Fe and other plant nutrients. 
Table 7. Nitrogen $(N)$, phosphorus $(P)$, potassium $(K)$ and iron $(F e)$ nutrient contents of the shoot of BRS 6970IPRO soybean plants, treated with beneficial microorganisms, isolated and in combination.

\begin{tabular}{|c|c|c|c|c|}
\hline \multirow[t]{2}{*}{ Microorganism } & $\mathrm{N}$ & $P$ & $\mathrm{~K}$ & $\mathrm{Fe}$ \\
\hline & \multicolumn{4}{|c|}{ 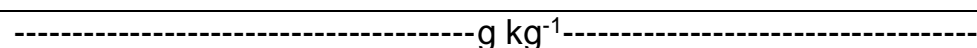 } \\
\hline 32109 & $46.42 \mathrm{abc}$ & $3.76 \mathrm{bcd}$ & $18.96 \mathrm{abc}$ & $97 \mathrm{bcd}$ \\
\hline 32110 & $48.76 \mathrm{a}$ & $3.87 \mathrm{abcd}$ & 17.38 abcdef & $96 \mathrm{~cd}$ \\
\hline 32111 & $46.65 a b$ & $3.85 \mathrm{bcd}$ & $18.72 \mathrm{abcd}$ & $120 \mathrm{a}$ \\
\hline 32112 & $45.46 a b c$ & $3.70 \mathrm{bcd}$ & $18.75 \mathrm{abcd}$ & $97 \mathrm{bcd}$ \\
\hline 32113 & 43.02 bcde & $3.44 \mathrm{~d}$ & $20 \mathrm{a}$ & $94 \mathrm{~cd}$ \\
\hline 32114 & $44.43 \mathrm{abcd}$ & $3.62 \mathrm{~cd}$ & 17.63 abcde & $94 \mathrm{~cd}$ \\
\hline 1301 & $46.32 \mathrm{abc}$ & $4.03 a b c$ & $19.04 \mathrm{ab}$ & $101 \mathrm{abcd}$ \\
\hline 1381 & $41.97 \mathrm{cde}$ & $3.57 \mathrm{~cd}$ & 16.74 bcdefg & $107 \mathrm{abcd}$ \\
\hline T. asperellum pool & $46 \mathrm{abc}$ & $3.71 \mathrm{bcd}$ & 16.93 abcdef & $113 \mathrm{abcd}$ \\
\hline Ab-V5 & $44.71 \mathrm{abcd}$ & $3.61 \mathrm{~cd}$ & 17.47 abcde & $95 \mathrm{~cd}$ \\
\hline $32114+32110$ & $45.12 \mathrm{abcd}$ & $3.79 \mathrm{bcd}$ & 16.92 abcdefg & $111 \mathrm{abcd}$ \\
\hline $32114+A b-V 5$ & $44.36 \mathrm{abcd}$ & $3.69 \mathrm{bcd}$ & $14.34 \mathrm{fgh}$ & $100 \mathrm{abcd}$ \\
\hline $32114+T$. asperellum pool & $46.69 \mathrm{ab}$ & $3.96 \mathrm{abcd}$ & 14.89 efgh & $101 \mathrm{abcd}$ \\
\hline $32110+A b-V 5$ & $46.70 \mathrm{ab}$ & $4.07 \mathrm{abc}$ & 14.72 efgh & 99 abcd \\
\hline $32110+T$. asperellum pool & $45.02 \mathrm{abcd}$ & $4.34 \mathrm{a}$ & 14.73 efgh & $103 \mathrm{abcd}$ \\
\hline $\mathrm{Ab}-\mathrm{V} 5+T$. asperellum pool & 42.60 bcde & $4.15 \mathrm{ab}$ & 14.91 efgh & $112 \mathrm{abcd}$ \\
\hline $1381+1301$ & $41.96 \mathrm{cde}$ & $4.16 \mathrm{ab}$ & 14.77 efgh & $103 \mathrm{abcd}$ \\
\hline $1381+A b-V 5$ & $40.77 \mathrm{de}$ & $3.66 \mathrm{bcd}$ & 16.06 bcdefgh & $96 \mathrm{bcd}$ \\
\hline $1301+A b-V 5$ & $44.09 \mathrm{bcd}$ & $3.62 \mathrm{~cd}$ & $14.11 \mathrm{gh}$ & $100 \mathrm{abcd}$ \\
\hline $1381+32114$ & $39.31 \mathrm{e}$ & $3.75 \mathrm{bcd}$ & $14.32 \mathrm{fgh}$ & $114 \mathrm{abcd}$ \\
\hline $1301+32114$ & $44.43 \mathrm{abcd}$ & $3.70 \mathrm{bcd}$ & 15.52 efgh & $92 \mathrm{~d}$ \\
\hline $1381+32110$ & 43.73 bcde & $3.60 \mathrm{~cd}$ & 14.56 efgh & $119 a b$ \\
\hline $1301+32110$ & 43.78 bcde & $3.58 \mathrm{~cd}$ & 15.88 cdefgh & $93 d$ \\
\hline $1381+T$. asperellum pool & $45.42 a b c$ & $3.90 \mathrm{abcd}$ & $13.33 \mathrm{~h}$ & $116 a b c$ \\
\hline $1301+T$. asperellum pool & 43.45 bcde & $3.62 \mathrm{~cd}$ & 15.78 defgh & $109 \mathrm{abcd}$ \\
\hline No microorganism & $44.36 \mathrm{abcd}$ & $3.64 \mathrm{bcd}$ & 16.17 bcdefgh & $94 \mathrm{~d}$ \\
\hline
\end{tabular}

* Means followed by the same letter do not differ from each other by the LSD test. BRM 32109, BRM 32110 and 1381 Bacillus sp., BRM 32111 Burkholderia sp., BRM 32112 and BRM 32113 - Pseudomonas sp, Ab-V5 - Azospirillum sp., 1301 - Azospirillum brasilense, T.asperellum pool (UFRA-06, UFRA- 09, UFRA-12 and UFRA-52).

Regarding the root nutrient accumulation, no treatment differed from the control for $\mathrm{N}, \mathrm{P}$ and Fe (Table 8). For $\mathrm{N}$, treatments BRM 32114, BRM 32112, $1381+\mathrm{Ab}-\mathrm{V} 5,1381+32114$ and $1301+T$. asperellum pool were significantly higher than treatments $32114+\mathrm{Ab}-\mathrm{V} 5$ and $1301+32110$. For $\mathrm{P}$, only treatment BRM 32113 was significantly superior to treatments $1301+32110,32110+T$. asperellum pool, $32114+\mathrm{Ab}-\mathrm{V} 5$, $\mathrm{Ab}-\mathrm{V} 5$ and T. asperellum pool treatments. For iron (Fe), the treatments Ab-V5, 1301, $32114+\mathrm{Ab}-\mathrm{V} 5,1301$ $+32110, T$. asperellum pool, $1381+32110$ and $1301+32114$ were significantly higher than treatments 1301 $+T$. asperellum pool and 32114 .

Differently, for $\mathrm{K}$, the treatments BRM 32111, BRM 32112, BRM 32114, BRM 32113, BRM 32110 and $1381+32114$ provided higher accumulation in the roots when compared to the control (Table 8). As already mentioned, the $\mathrm{K}$ accumulation in the soybean roots can be a result of your increased soil solution availability. In evaluating carrot plants that were inoculated with rhizobacteria isolated from the Crotalaria spectabilis rhizosphere, [27] found higher $\mathrm{K}$ content in plant roots. 
Table 8. Nitrogen $(\mathrm{N})$, phosphorus $(\mathrm{P})$, potassium $(\mathrm{K})$ and iron $(\mathrm{Fe})$ nutrient contents of root of BRS 6970IPRO soybean plants, treated with beneficial microorganisms, isolated and in combination.

\begin{tabular}{lllll}
\hline Microorganism & $\mathrm{N}$ & $\mathrm{P}$ & $\mathrm{K}$ & $\mathrm{Fe}$ \\
\cline { 2 - 5 } 32109 & $14.16 \mathrm{abc}$ & $1.25 \mathrm{bc}$ & $3.38 \mathrm{defg}$ & $47.05 \mathrm{abcde}$ \\
32110 & $13.37 \mathrm{abc}$ & $1.33 \mathrm{abc}$ & $5.20 \mathrm{abcd}$ & $46.51 \mathrm{abcde}$ \\
32111 & $13.50 \mathrm{abc}$ & $1.45 \mathrm{abc}$ & $5.77 \mathrm{a}$ & $37.94 \mathrm{abcdef}$ \\
32112 & $16.05 \mathrm{a}$ & $1.90 \mathrm{a}$ & $5.67 \mathrm{ab}$ & $36.83 \mathrm{bcdef}$ \\
32113 & $13.93 \mathrm{abc}$ & $1.53 \mathrm{abc}$ & $5.49 \mathrm{abc}$ & $41.93 \mathrm{abcdef}$ \\
32114 & $16.06 \mathrm{a}$ & $1.55 \mathrm{abc}$ & $5.66 \mathrm{ab}$ & $31.88 \mathrm{ef}$ \\
1301 & $10.57 \mathrm{bc}$ & $1.27 \mathrm{abc}$ & $3.34 \mathrm{efg}$ & $53.31 \mathrm{ab}$ \\
1381 & $13.87 \mathrm{abc}$ & $1.47 \mathrm{abc}$ & $4.77 \mathrm{abcdefg}$ & $41.54 \mathrm{abcdef}$ \\
$T$. asperellum pool & $10.82 \mathrm{abc}$ & $1.23 \mathrm{bc}$ & $4.02 \mathrm{abcdefg}$ & $50.56 \mathrm{abc}$ \\
Ab-V5 & $10.78 \mathrm{abc}$ & $1.23 \mathrm{bc}$ & $3.78 \mathrm{cdefg}$ & $53.54 \mathrm{a}$ \\
$32114+32110$ & $13.75 \mathrm{abc}$ & $1.35 \mathrm{abc}$ & $3.08 \mathrm{~g}$ & $38.90 \mathrm{abcdef}$ \\
$32114+$ Ab-V5 & $9.39 \mathrm{c}$ & $1.19 \mathrm{bc}$ & $3.66 \mathrm{cdefg}$ & $52.68 \mathrm{ab}$ \\
$32114+$ T. asperellum pool & $14.12 \mathrm{abc}$ & $1.82 \mathrm{ab}$ & $3.74 \mathrm{cdefg}$ & $35.36 \mathrm{cdef}$ \\
$32110+$ Ab-V5 & $14.42 \mathrm{abc}$ & $1.60 \mathrm{abc}$ & $3.96 \mathrm{abcdefg}$ & $39.93 \mathrm{abcdef}$ \\
$32110+$ T. asperellum pool & $10.64 \mathrm{abc}$ & $1.24 \mathrm{bc}$ & $3.67 \mathrm{cdefg}$ & $50.50 \mathrm{abc}$ \\
Ab-V5 + T. asperellum pool & $13.90 \mathrm{abc}$ & $1.49 \mathrm{abc}$ & $3.89 \mathrm{bcdefg}$ & $33.88 \mathrm{def}$ \\
$1381+1301$ & $11.26 \mathrm{abc}$ & $1.55 \mathrm{abc}$ & $4.26 \mathrm{abcdefg}$ & $48.21 \mathrm{abcde}$ \\
$1381+$ Ab-V5 & $14.87 \mathrm{ab}$ & $1.61 \mathrm{abc}$ & $3.83 \mathrm{bcdefg}$ & $39.24 \mathrm{abcdef}$ \\
$1301+$ Ab-V5 & $12.41 \mathrm{abc}$ & $1.47 \mathrm{abc}$ & $3.38 \mathrm{defg}$ & $46.48 \mathrm{abcde}$ \\
$1381+32114$ & $14.87 \mathrm{ab}$ & $1.74 \mathrm{abc}$ & $5.04 \mathrm{abcde}$ & $39.27 \mathrm{abcdef}$ \\
$1301+32114$ & $13.65 \mathrm{abc}$ & $1.57 \mathrm{abc}$ & $3.91 \mathrm{bcdefg}$ & $48.79 \mathrm{abcd}$ \\
$1381+32110$ & $10.65 \mathrm{abc}$ & $1.34 \mathrm{abc}$ & $4.25 \mathrm{abcdefg}$ & $48.97 \mathrm{abcd}$ \\
$1301+32110$ & $8.98 \mathrm{c}$ & $1.18 \mathrm{c}$ & $3.32 \mathrm{efg}$ & $50.99 \mathrm{abc}$ \\
$1381+$ T. asperellum pool & $12.10 \mathrm{abc}$ & $1.43 \mathrm{abc}$ & $2.99 \mathrm{~g}$ & $43.09 \mathrm{abcdef}$ \\
$1301+$ T. asperellum pool & $15.76 \mathrm{ab}$ & $1.75 \mathrm{abc}$ & $4.94 \mathrm{abcdef}$ & $29.34 \mathrm{f}$ \\
\hline No microorganism & $11.52 \mathrm{abc}$ & $1.59 \mathrm{abc}$ & $3.13 \mathrm{fg}$ & $49.76 \mathrm{abcd}$ \\
\hline
\end{tabular}

${ }^{*}$ Means followed by the same letter do not differ from each other by the LSD test. BRM 32109, BRM 32110 and 1381 Bacillus sp., BRM 32111 Burkholderia sp., BRM 32112 and BRM 32113 - Pseudomonas sp, Ab-V5 - Azospirillum sp., 1301 - Azospirillum brasilense, T.asperellum pool (UFRA-06, UFRA- 09, UFRA-12 and UFRA-52).

No treatments differed from the control treatment in the accumulation of macronutrients $\mathrm{N}, \mathrm{P}$ and $\mathrm{K}$ in the grains (Table 9). Treatments $1301+T$. asperellum pool, BRM 32110 , BRM 32112 and 1381 accumulated more $\mathrm{N}$ than treatment 32111 . In relation to $\mathrm{P}$, treatments $1301+32110,32114+T$. asperellum pool and $32110+T$. asperellum pool were significantly higher than treatments BRM 32109, BRM 32111, Ab-V5, T. asperellum pool, 1381, BRM 32114, BRM 32112, BRM 32113 and $1381+32114$. The treatments BRM 32114, T. asperellum pool, $1301,32114+\mathrm{Ab}-\mathrm{V} 5,32114+\mathrm{T}$. asperellum pool and $32110+\mathrm{Ab}-\mathrm{V} 5$ accumulated higher amount of $\mathrm{K}$ than treatments $\mathrm{Ab}-\mathrm{V} 5,1381+32110,1301+32110$ and $32110+T$. asperellum pool.

The BRM 32113 microorganism differed significantly from control treatment for grain Fe accumulation (Table 9). Nutrient concentration in the seed is expressed as a function of the values found in the constituent reserve part. These values may vary among species, cultivars, and also the environmental conditions to which they are subjected. Nutrients stored in the seeds are essential because they are responsible for maintaining the seedling in the first days of emergence and also allow more nutritious grain for food [28]. Emphasis should be given to the isolate BRM 32113 in relation to the nutrient accumulation of soybean plants, as it provided higher $\mathrm{K}$ content in shoots and roots and $\mathrm{Fe}$ in grains. The greater absorption of nutrients by plants treated with beneficial microorganisms is due, in part, to the greater development of the roots and the increase of the root hairs [29]. Higher root growth can be stimulated by the production of phytohormones allowing greater access to nutrients and, therefore, greater absorption of these. 
Table 9. Nitrogen $(\mathrm{N})$, phosphorus $(\mathrm{P})$, potassium $(\mathrm{K})$ and iron $(\mathrm{Fe})$ nutrient contents of grains of BRS 6970IPRO soybean plants, treated with beneficial microorganisms, isolated and in combination.

\begin{tabular}{lllll}
\hline Microorganism & $\mathrm{N}$ & $\mathrm{P}$ & $\mathrm{K}$ & $\mathrm{Fe}$ \\
\cline { 2 - 5 } 32109 & $----\mathrm{-a} \mathrm{abcd}$ & $4.81 \mathrm{f}$ & $13.57 \mathrm{abcd}$ & $72.48 \mathrm{ab}$ \\
32110 & $57.44 \mathrm{ab}$ & $5.36 \mathrm{abcde}$ & $12.90 \mathrm{abcdef}$ & $54.52 \mathrm{bc}$ \\
32111 & $55.12 \mathrm{~d}$ & $4.90 \mathrm{ef}$ & $13.36 \mathrm{abcde}$ & $59.34 \mathrm{bc}$ \\
32112 & $57.35 \mathrm{ab}$ & $5.07 \mathrm{cdef}$ & $13.57 \mathrm{abcd}$ & $55.12 \mathrm{bc}$ \\
32113 & $56.05 \mathrm{abcd}$ & $5.07 \mathrm{cdef}$ & $13.15 \mathrm{abcdef}$ & $89.81 \mathrm{a}$ \\
32114 & $55.96 \mathrm{abcd}$ & $5.05 \mathrm{cdef}$ & $13.99 \mathrm{a}$ & $60.97 \mathrm{bc}$ \\
1301 & $56.21 \mathrm{abcd}$ & $5.25 \mathrm{abcdef}$ & $13.84 \mathrm{abc}$ & $62.12 \mathrm{bc}$ \\
1381 & $57.23 \mathrm{abc}$ & $5.04 \mathrm{cdef}$ & $13.37 \mathrm{abcde}$ & $57.00 \mathrm{bc}$ \\
$T$. asperellum pool & $55.45 \mathrm{bcd}$ & $5.02 \mathrm{cdef}$ & $13.92 \mathrm{ab}$ & $59.38 \mathrm{bc}$ \\
Ab-V5 & $56.55 \mathrm{abcd}$ & $4.95 \mathrm{def}$ & $12.06 \mathrm{f}$ & $65.16 \mathrm{bc}$ \\
$32114+32110$ & $55.81 \mathrm{abcd}$ & $5.34 \mathrm{abcde}$ & $13.44 \mathrm{abcde}$ & $66.78 \mathrm{bc}$ \\
$32114+$ Ab-V5 & $56.06 \mathrm{abcd}$ & $5.45 \mathrm{abc}$ & $13.84 \mathrm{abc}$ & $73.36 \mathrm{ab}$ \\
$32114+$ T. asperellum pool & $55.86 \mathrm{abcd}$ & $5.63 \mathrm{ab}$ & $13.84 \mathrm{abc}$ & $65.81 \mathrm{bc}$ \\
$32110+$ Ab-V5 & $56.97 \mathrm{abcd}$ & $5.35 \mathrm{abcde}$ & $13.83 \mathrm{abc}$ & $64.05 \mathrm{bc}$ \\
$32110+$ T. asperellum pool & $55.75 \mathrm{abcd}$ & $5.61 \mathrm{ab}$ & $12.56 \mathrm{def}$ & $68.18 \mathrm{bc}$ \\
Ab-V5 + T. asperellum pool & $55.25 \mathrm{~cd}$ & $5.08 \mathrm{cdef}$ & $13.52 \mathrm{abcde}$ & $53.61 \mathrm{bc}$ \\
$1381+1301$ & $57.15 \mathrm{abcd}$ & $5.24 \mathrm{abcdef}$ & $12.74 \mathrm{bcdef}$ & $61.25 \mathrm{bc}$ \\
$1381+$ Ab-V5 & $56.94 \mathrm{abcd}$ & $5.36 \mathrm{abcde}$ & $12.73 \mathrm{bcdef}$ & $60.97 \mathrm{bc}$ \\
$1301+$ Ab-V5 & $57.04 \mathrm{abcd}$ & $5.42 \mathrm{abcd}$ & $13.50 \mathrm{abcde}$ & $61.57 \mathrm{bc}$ \\
$1381+32114$ & $56.26 \mathrm{abcd}$ & $5.11 \mathrm{cdef}$ & $12.87 \mathrm{abcdef}$ & $47.94 \mathrm{c}$ \\
$1301+32114$ & $55.71 \mathrm{bcd}$ & $5.18 \mathrm{bcdef}$ & $12.81 \mathrm{abcdef}$ & $69.05 \mathrm{~b}$ \\
$1381+32110$ & $56.26 \mathrm{abcd}$ & $5.47 \mathrm{abc}$ & $12.37 \mathrm{ef}$ & $68.91 \mathrm{~b}$ \\
$1301+32110$ & $56.70 \mathrm{abcd}$ & $5.69 \mathrm{a}$ & $12.40 \mathrm{def}$ & $71.68 \mathrm{ab}$ \\
$1381+$ T. asperellum pool & $57.77 \mathrm{a}$ & $5.49 \mathrm{abc}$ & $13.39 \mathrm{abcde}$ & $55.22 \mathrm{bc}$ \\
$1301+$ T. asperellum pool & $56.17 \mathrm{abcd}$ & $5.43 \mathrm{abcd}$ & $13.22 \mathrm{abcdef}$ & $62.73 \mathrm{bc}$ \\
\hline No microorganism & $56.88 \mathrm{abcd}$ & $5.33 \mathrm{abcde}$ & $13.05 \mathrm{abcdef}$ & $60.25 \mathrm{bc}$ \\
\hline
\end{tabular}

* Means followed by the same letter do not differ from each other by the LSD test. BRM 32109, BRM 32110 and 1381 - Bacillus sp., BRM 32111 Burkholderia sp., BRM 32112 and BRM 32113 - Pseudomonas sp, Ab-V5 - Azospirillum sp., 1301 - Azospirillum brasilense, T.asperellum pool (UFRA-06, UFRA- 09, UFRA-12 and UFRA-52).

The Ab-V5 (Azospirillum brasilense) $+T$. asperellum pool co-inoculation was the treatment that provided number of pods per plant, 100 grain weight and soybean yield significantly higher than the control treatment (Table 10). For the number of grains per pod, the treatments BRM 32113; BRM 32111; 1301; T. asperellum pool; $1301+$ Ab-V5; $1381+$ BRM 32114 and BRM $32114+$ Ab-V5 were superior compared to control treatment. (Table 10). In a study conducted by [30], soybean co-inoculation with Bradyrhizobium spp. and $A$. brasilense provided a $16 \%$ increase in grain yield compared to the control treatment (without inoculation). While [31] found that the application of Trichoderma sp. Soybean seeds and sprouts yielded $12 \%$ higher grain yield than control plants (without inoculation). These results allow inferring that soybean plants treated with rhizobium and co-inoculated with beneficial microorganisms increased their growth and grain yield significantly. Since the '90s, [32] had already described that $A$. brasilense, associated with Bradhyrizobium, can bring benefits to soybean crop, such as higher development, higher nodulation, BNF efficiency and higher grain yield. While [33] reported that $T$. asperellum could promote higher growth and yield of soybean plants through the production of phytohormones, higher nutrient absorption and use efficiency, in addition to greater control of harmful microorganisms. 
Table 10. Number of pods per plant (NPP), the number of grains per pod (NGP), mass of 100 grains (M100) and grain yield (GY) of soybean, BRS 6970IPRO, co-inoculated with beneficial microorganisms, isolated and in combination.

\begin{tabular}{|c|c|c|c|c|}
\hline \multirow[t]{2}{*}{ Microorganism } & NPP & NGP & M100 & GY \\
\hline & Unit & Unit & $g$ & $\mathrm{~g} \mathrm{plant}^{-1}$ \\
\hline 32109 & 46.50 bcdef & 1.96 cdef & $18.61 \mathrm{bc}$ & 34.00 cde \\
\hline 32110 & 51.75 abcde & 2.07 abcde & $18.16 \mathrm{bc}$ & 28.60 abcde \\
\hline 32111 & 40.62 ef & $2.15 a b$ & $19.37 \mathrm{ab}$ & $33.84 \mathrm{de}$ \\
\hline 32112 & 49 bcdef & 1.96 def & $18.42 \mathrm{bc}$ & 35.08 bcde \\
\hline 32113 & $39.37 \mathrm{f}$ & $2.17 \mathrm{a}$ & $19.37 \mathrm{ab}$ & $33.04 \mathrm{e}$ \\
\hline 32114 & 44.75 cdef & 2.06 abcde & $18.92 \mathrm{abc}$ & 34.87 cde \\
\hline 1301 & 51.62 abcde & $2.14 \mathrm{ab}$ & $17.63 \mathrm{c}$ & 38.82 abcde \\
\hline 1381 & $57.50 \mathrm{abc}$ & 1.98 bcde & $18.56 \mathrm{bc}$ & $41.97 \mathrm{abcd}$ \\
\hline Trichoderma pool & 44.12 cdef & $2.14 \mathrm{ab}$ & $18.59 \mathrm{bc}$ & 34.45 cde \\
\hline$A b-V 5$ & 41.62 def & 2.07 abcde & $19.28 \mathrm{abc}$ & $33.10 \mathrm{e}$ \\
\hline $32114+32110$ & 52.12 abcde & 2.04 abcde & $18.96 \mathrm{abc}$ & 40.28 abcde \\
\hline $32114+A b-V 5$ & 44.37 cdef & $2.11 \mathrm{abcd}$ & $19.41 \mathrm{ab}$ & 36.35 abcde \\
\hline $32114+$ T. pool & 43.50 cdef & 2.05 abcde & $18.43 \mathrm{bc}$ & $32.88 \mathrm{e}$ \\
\hline $32110+A b-V 5$ & 50.50 abcdef & 2.05 abcde & $18.39 \mathrm{bc}$ & 38.34 abcde \\
\hline $32110+T$. pool & $53.00 \mathrm{abcd}$ & 2 abcde & $18.24 \mathrm{bc}$ & 39.08 abcde \\
\hline $\mathrm{Ab}-\mathrm{V} 5+T$. pool & $61.87 \mathrm{a}$ & $1.80 \mathrm{f}$ & $20.51 \mathrm{a}$ & $44.42 \mathrm{a}$ \\
\hline $1381+1301$ & $54.62 \mathrm{abcd}$ & 1.99 abcde & $19.21 \mathrm{abc}$ & $42.01 \mathrm{abc}$ \\
\hline $1381+A b-V 5$ & 51.75 abcde & 2.07 abcde & $18.83 \mathrm{abc}$ & 40.04 abcde \\
\hline $1301+A b-V 5$ & 47.87 abcdef & $2.13 \mathrm{abcd}$ & $18.95 \mathrm{abc}$ & 38.15 abcde \\
\hline $1381+32114$ & 47.12 abcdef & $2.13 \mathrm{abc}$ & $18.63 \mathrm{bc}$ & 37.38 abcde \\
\hline $1301+32114$ & 49.87 abcdef & 2.04 abcde & $18.25 \mathrm{bc}$ & 37.24 abcde \\
\hline $1381+32110$ & 50.50 abcef & 2.07 abcde & $18.63 \mathrm{bc}$ & 38.94 abcde \\
\hline $1301+32110$ & 42.75 cdef & 2.10 abcde & $19.01 \mathrm{abc}$ & 34.06 cde \\
\hline $1381+T$. pool & $54.37 \mathrm{abc}$ & 2.08 abcde & $19.31 \mathrm{abc}$ & $43.07 \mathrm{ab}$ \\
\hline $1301+T$. pool & $53.12 \mathrm{abcd}$ & 1.93 ef & $18.75 \mathrm{bc}$ & $38.60 \mathrm{abcde}$ \\
\hline No microorganism & 49.62 bcdef & 1.93 ef & $18.48 \mathrm{bc}$ & 35.49 bcde \\
\hline
\end{tabular}

${ }^{*}$ Means followed by the same letter do not differ from each other by the LSD test. BRM 32109, BRM 32110 and 1381 - Bacillus sp., BRM 32111 Burkholderia sp., BRM 32112 and BRM 32113, Pseudomonas sp, Ab-V5 - Azospirillum sp., 1301 - Azospirillum brasilense, T.asperellum pool (UFRA-06, UFRA- 09, UFRA-12 and UFRA-52).

In summary, we highlight the co-inoculation of the $\mathrm{Ab}-\mathrm{V} 5+T$. asperellum pool, as it provided, on average, $25 \%$ increase in soybean yield (Table 10). These results can be explained by the higher number of pods per plant and a higher mass of 100 grains. Isolate Ab-V5 (Azospirillum brasilense) and T. asperellum are the only microorganisms in this study that are already commercially used as growth promoters in various crops and have their proven benefits, especially in higher soybean yield.

The association of PGPR and fungi, such as Trichoderma sp., with plants, expands the zone of root absorption, increasing the contact surface with the soil, favoring greater absorption of nutrients such as $P$, zinc, copper and $\mathrm{K}$ [34] and $\mathrm{N}$ [35], resulting in increased plant tolerance to abiotic and biotic stresses [36]. Similarly, PGPR provide an increase in plant yield by the ability to increase the efficiency of nutrient uptake, especially low mobility such as $\mathrm{Fe}$ and $\mathrm{P}$. Besides the function of fixing the $\mathrm{N}$ from the air in the roots, some selected bacteria have the capacity to make soluble the phosphorus present in the soil and make it available to the vegetable [37]. They can also produce auxins such as indole-3-acetic acid, increasing the root length of the plants, thus leading to greater uptake of nutrients from the soil [38]. All these characteristics together can provide higher soybean grain yield in comparison to the control treatments, as observed in our trial.

Our results are promising and highlight the potential of a combination of beneficial microorganisms coinoculated with Bradyrhizobium on soybean growth/ development. Positive physio-agronomic responses such as the increase of photosynthetic rate and carboxylation efficient, nutrients content, dry matter production and grain yield were obtained. Emphasis should be given to the technology used, beneficial microorganisms, where it is the low cost of investment, easy application and use, not polluting, and it is part of a desired sustainable context in modern agriculture. In addition, the results are even more relevant because they are microorganisms that were selected from the rice root system [4] and provided growth improvement in the soybean plant. Industries are looking for beneficial microorganisms that provide improvements in several crops for economic purposes. The same species of beneficial microorganisms can lead to greater growth and development of plants in several species [39,9]. The results are commercially important as these microorganisms have yielded good results in irrigated rice [7], upland rice [8] and soybean crops (present trial). Our focus is to evaluate the performance of beneficial microorganisms in production 
systems (field conditions) since they recommend the rotation of crops as one of the main pillars for the sustainable intensification of agriculture. Therefore, additional studies should be performed under field conditions to confirm the good results obtained under controlled conditions.

The effect of beneficial microorganisms on physiological activities, biomass production, nutrient accumulation and crop yields varies in laboratory, greenhouse and field trials. Because soil is an unpredictable environment and sometimes makes it difficult to achieve an intentional result. Climate variations also have a major impact on the effectiveness of microorganisms, as well as the presence of other natural soil microorganisms, but sometimes unfavorable growth conditions in the field are expected as normal agricultural functioning [40]. There are several studies performed with the genera of microorganisms tested in this study and several others that report their ability to stimulate plants through substances that promote plant growth through different mechanisms of action, which are still being investigated [41]. Thus, research conducted in this sector demands to understand the development of these microorganisms in the plant, seeking the effectiveness of this technique, the development of new management methods that ultimately enable high production and low use of fertilizers. Various other researches on different crops, microorganisms, and environmental conditions must be undertaken to find the most efficient species of microorganisms in different conditions and also for each crop and region.

\section{CONCLUSION}

The tested microorganisms provided increases in gas exchange, biomass production, yield components, grain yield and nutrient accumulation in soybean biomass.

The mixture of the microorganisms $\mathrm{Ab}-\mathrm{V} 5+T$. asperellum pool provided the highest grain yield of soybean, being $25 \%$ higher than the control treatment. These results can be explained by the greater number of pods and a mass of 100 grains provided the soybean plants by this mixture of microorganisms.

Funding: This research was funded by CNPq, grant number 406507/2018-0 and FAPEG grant number 201410267001713.

Acknowledgments: The authors are grateful to Embrapa for the infrastructure for conducting the research and also to the CNPq for the master's degree awarded to the first author, and for the scholarship in research productivity to the second and third authors.

Conflicts of Interest: The authors declare no conflict of interest.

\section{REFERENCES}

1. Nonato JJ. Nutrição, fisiologia e produtividade de soja inoculada com Azospirillum brasilense e reguladores vegetais [dissertation]. Guarapuava -PR: Faculdade de Agronomia, Universidade Estadual do Centro-Oeste; 2016. 79 p.

2. Steffen GPK, Maldaner J, Missio EL e Steffen RB. Trichoderma controla fitonematóides e aumenta produtividade da soja [Internet]. Riber Solo, Ribeirão preto, São Paulo. 2018 [cited 2019 Mar 29]. Available from: https://www.agricultura.rs.gov.br/upload/arquivos/201804/12095822-uso-de-trichoderma-na-agricultura.pdf

3. Samuels GJ. Trichoderma: Systematics, the sexual state, and ecology. Phytopathology. 2006 Feb; 96 (2): 195-206.

4. Filippi MCC, Silva GB, Silva-Lobo VL, Cortes MMCB, Moraes AJG, Prabhu AS. Leaf blast (Magnaporthe oryzae) suppression and growth promotion by rhizobacteria on aerobic rice in Brazil. Biol Control. 2011 Aug; 58 (2):160-166.

5. Silva MA, Jifon JL, Santos CM, Jadoski Junior C, Silva JAG. Photosynthetic Capacity and Water Use Efficiency in Sugarcane Genotypes Subject to Water Deficit During Early Growth Phase, Braz Arch Biol Technol. 2013 Oct; 56 (5): 735-748.

6. França SKS, Cardoso AF, Lustosa DC, Ramos MLS, Filippi MCC, Silva GB. Biocontrol of sheath blight by Trichoderma asperellum in tropical lowland rice. Agron Sustain Dev. 2015 Aug; 35:317-324.

7. Nascente AS, Filippi MCC, Lanna AC, Souza, ACA, Lobo VLS, Silva G. Biomass, gas exchange, and nutrient contents in upland rice plants affected by application forms of microorganism growth promoters. Environ Sci Pollut R. 2017 Nov; 24 (3):2956-2965.

8. Sperandio EM, Vale HMM, Reis MS, Cortes MVCB, Lanna AC, Filippi MCC. Evaluation of rhizobacteria in uplant rice in Brazil: growth promotion and interaction of induced defense responses against leaf blast (Magnaporthe oryzae). Acta Physiol Plant. 2017 Dec; 39 (12): 258-270.

9. Ahemad M, Kibret M. Mechanisms and applications of plant growth promoting rhizobacteria: Current perspective. J King Saud Uni. 2014 May; 26 (1): 1-20.

10.Santos HG et al. Sistema brasileiro de classificação de solos. 5nd ed. rev. e ampl. 486. Rio de Janeiro: Centro Nacional de Pesquisa de Solos; 2018.

11.Donagema GK, Campos DVB, Calderano SB, Teixeira WG, Viana JHM (Org.). Manual de métodos de análise do solo. 2.ed. rev. Rio de Janeiro: Embrapa Solos; 2011. 230p.

12. Martins BEM. Caracterização morfológica, bioquímica e molecular de isolados bacterianos antagonistas a Magnaporthe oryzae [dissertation]. Universidade Federal de Goiás; 2015. 80 p. 
13. Kado CJ, Heskett MG. Selective media for isolation of Agrobacterium, 401 Corynebacterium, Erwinia, Pseudomonas and Xanthomonas. Phytopathology. 1970 Jan; 60:969- 976.

14.Malavolta E, Vitti GC, Oliveira, AS. Avaliação do estado nutricional de plantas: princípios e aplicações. PiracicabaSP: Associação Brasileira para Pesquisa da Potassa e do Fosfato;1997.

15. Hungria et al. Biology and Fertility of Soils. 2013;49:791-801.

16. Maurício Filho JM, Silva CHS, Souza JEB. Desempenho agronômico e produtividade da cultura da soja com a coinoculação de Bradyrhizobium e Azospirillum brasilense. Ipê Agronomic Journal. 2018 Nov; 2(2):48-59

17.Braga Júnior G M, Chagas LFB, Amaral L RO.; Miller LO, Ghagas Júnior A F. Efficiency of inoculation by Bacillus subtilis on soybean biomass and productivity. Agrária. 2018 Jun; 13 (4): $36 .$.

18.Santi C, Bogusz D, Franche C. Biological nitrogen fixation in non-legume plants. Ann. Bot. 2013 Mar; 111 (5): $743-$ 767.

19.Glick BR, Patten CL, Holguin G, Penrose DM. Biochemical and genetic mechanisms used by plant growth-promoting bacteria. London: Imperial College Press. 1995.

20.Braga Júnior GM, Chagas LFB, Colonia BSO, Scheidt GN. Soybean growth promotion and phosphate solubilization by bacillus subtilis strains in greenhouse. Int J Curr Res. 2017 May; 9(5):50914-50918.

21.Saravanakumar K, Arasu VS, Kathiresan K. Effect of Trichoderma on soil phosphate solubilization and growth improvement of Avicennia marina. Aquatic Botany. 2013 Oct; 104:101-105.

22. Bhattacharjee RB, Sing A, Mukhopadyay SN. Use of nitrogen-fixing bacteria as biofertilizer for non-legumes: prospects and challenges. Appl Microbiol Biotechnol, Heidelberg. 2008 Jul; 80(2):199-209.

23. Crosa JH, Walsh CT.Genetics and assembly line enzymology of siderophore biosynthesis in bacteria. Microbiol Mol Biol Rev. 2002 Jun; 66 (2):223-249.

24. Wandersman C, Delepelaire P.Bacterial iron sources: From siderophores to hemophores. Annu Rev Microbiol. 2004 Feb; 58 (1):611-647.

25.Dimkpa CO, Merten D, Svatos A, Büchel G, Kothe E. Siderophores mediate reduced and increased uptake of cadmium by Streptomyces tendae F4 and sunflower (Helianthus annuus), respectively. J Appl Microbiol. 2009 May; 107 (5):1687-1696.

26. Radzki W, Manero FG, Algar E, Garcia J L, Garcia VA, Solano BR. Bacterial siderophores efficiently provide iron to iron-starved tomato plants in hydroponics culture. Antonie Van Leeuwenhoek, Amsterdam. 2013 Jun; 104 (3):321330.

27.Andreani DIK, Agiado JC, Andreani Junior R. Efeito de bactérias rizosféricas sobre o desenvolvimento da cenoura. Rev. Univ. Vale Rio Verde. 2014 Jun; 12(1):211-220.

28.Carvalho NM, Nakagawa J. Sementes: Ciência, Tecnologia e Produção. Campinas, Fundação Cargil. 1988; 3:424.

29. Machado DFM et al. Trichoderma: o fungo e o bioagente. Agrária. 2012; 35(1).[cited 2020 Mar 29]. Available from: http://www.scielo.gpeari.mctes.pt/ pdf/rca/v35n1/v35n1a26.pdf.

30.Hungria M, Nogueira MA, Araujo RS. Tecnologia de coinoculação da soja com Bradyrhizobium e Azospirillum: incrementos no rendimento com sustentabilidade e baixo custo. In: Reunião de pesquisa de soja da região central do brasil, Londrina. 2013; 33.

31.Gai D. Avaliação de Trichoderma na cultura da soja. Trabalho de Conclusão de Curso (Curso de Agronomia), UNIJUÍ, ljuí. 2014; 39p.

32. Döbereiner J. History and new perspectives of diazotrophs in association with non-leguminous plants. Symbiosis. 1992; 13 (1-3):1-13.

33. Harman GE, Herrera-Estrella AH, Horwitz BA, Lorito M. Special issue: Trichoderma - from basic biology to biotechnology Microbiology. Microbiology. 2012 Jan; 158:1-2.

34.Bressan W, Siqueira JO, Vasconcellos CA, Purcino AAC. Fungos micorrízicos e fósforo, no crescimento, nos teores de nutrientes e na produção do sorgo e soja consorciados. Pesq. Agropec. Bras., 2001; 36 (2): 250-260.

35.Gupta ML, Prasad A, Ram M, Kumar S. Effect of vesicular-arbuscular mycorrhizal (VAM) fungus Glomus fasciculatum on the essential oil yield related characters and nutrient acquisition in the crops of different cultivars of menthol mint (Mentha arvensis) under field conditions. Bioresour Technol. 2002 Jan; 81 (1): 77-79.

36. Maia LC, Silveira NSS, Cavalcanti UMT. Interaction between arbuscular mycorrhizal fungi and root pathogens. In: RAI, M.K. (Org.). Handbook of Microbial Biofertilizers. New York: The Haworth Press. 2006; 325- 352.

37.Vessey JK. Plant growth promoting rhizobacteria as biofertilizers. Plant Soil. 2003 Aug; 255 (2): 571-586.

38. Yang J, Kloepper J W, Ryu CM. Rhizosphere bacteria help plants tolerate abiotic stress. Trends Plant Sci. USA. 2009 Dec;14 (1): $1-4$.

39. Mendes LW et al. Influence of resistance breeding in common bean on rhizosphere 446 microbiome composition and function. ISME Journal. 2018 Jan; 12 (1): 212-224.

40.Zaidi A, Khan MS, Ahemad M, Oves M. Plant growth promotion by phosphate solubilizing bacteria. Acta microbiol. immunol. Hung. 2009 Sep, 56 (3):263-284.

41.Bloemberg GV, Lugtenberg BJJ. Molecular basis of plant growth promotion and biocontrol by rhizobacteria. Curr opin plant biol. 2001 Aug; 4 (4):343-350.

(C) 2020 by the authors. Submitted for possible open access publication under the terms and conditions of the Creative Commons Attribution (CC BY NC) license (https://creativecommons.org/licenses/by-nc/4.0/). 